\title{
Biophotonics Master studies: teaching and training experience at University of Latvia
}

Janis Spigulis

Janis Spigulis, "Biophotonics Master studies: teaching and training experience at University of Latvia," Proc. SPIE 9665, Tenth International Topical Meeting on Education and Training in Optics and Photonics, 96651C (3 June 2007); doi: $10.1117 / 12.2207536$

SPIE Event: Tenth International Topical Meeting on Education and Training in Optics and Photonics, 2007, Ottawa, Ontario, Canada 


\title{
Biophotonics Master studies: teaching and training experience at University of Latvia
}

\author{
Janis Spigulis \\ Bio-optics and Fiber Optics Laboratory, Institute of Atomic Physics and Spectroscopy \\ University of Latvia, 19 Raina Blvd., Riga, LV-1586, Latvia \\ Tellfax+371 7228249, e-mail: janispi@latnet.lv
}

\begin{abstract}
Two-year program for Master's studies on Biophotonics (Biomedical Optics) has been originally developed and carried out at University of Latvia since 1995. The Curriculum contains basic subjects like Fundamentals of Biomedical Optics, Medical Lightguides, Anatomy and Physiology, Lasers and Non-coherent Light Sources, Basic Physics, etc. Student laboratories, special English Terminology and Laboratory-Clinical Praxis are also involved as the training components, and Master project is the final step for the degree award. Life-long learning is supported by several E-courses and an extensive short course for medical laser users "Lasers and Bio-optics in Medicine". Recently a new inter-university European Social Fund project was started to adapt the program accordingly to the Bologna Declaration guidelines.
\end{abstract}

Keywords: biophotonics Master's study programs, biomedical optics education, lasers in medicine.

\section{INTRODUCTION}

Biophotonics is a subject related to photonic phenomena in biological media, e.g. living tissues; it can be regarded as a parallel term to "Biomedical Optics" or "Bio-optics", also frequently used in scientific community. A Master level subprogram "Biomedical Optics" was originally developed at University of Latvia and started in Faculty of Physics and Mathematics in year 1995. The Curriculum (total 80 credits) includes the main special subjects "Biomedical Optics - 1" (tissue optics and optical bio-sensing), "Biomedical Optics - 2" (lasers in medicine), "Medical Lightguides", "Anatomy", "Physiology", "English Terminology of Biomedical Optics" etc., as well as selected chapters of Basic Physics, laboratory training ( 2 general physics lab-sets and 5 special student labs) and Laboratory-Clinical Praxis. The studies take four semesters - three for lectures and practical training, and one for the Master project.

This paper presents details of the Curriculum and shares the 12-year experience regarding its implementation. Some novelties of the teaching and training approaches in addition to those reported previously ${ }^{1-3}$ are regarded, as well.

\section{THE CURRICULUM}

The actual Curriculum for the two-year/four-semester Master's studies in Riga is presented in Table 1. There are two main parts - part A is compulsory for all physics Master students, and part B is specific for the students specialized in Biophotonics (Biomedical Optics). The corresponding semesters and credits for each course are given, as well. Total number of credits to be collected is 80 . The credits awarded at University of Latvia may be transferred by means of the European Credit Transfer (ECT) system: 1 UL credit is equal to 1.5 European credits. One credit corresponds to 16-20 contact hours plus 20 hours of individual studies. Bachelor degree in natural sciences or engineering is a prerequisite to be enrolled as a Master student in this sub-program without entrance exams; candidates with medical background have to pass entrance exam in General Physics. The courses are presented in Latvian language; however, individual studies in English are also possible under agreement with the International Department ${ }^{4}$. Visiting students from Canada, Sweden and Bangladesh have been taught in English so far.

Tenth International Topical Meeting on Education and Training in Optics and Photonics, edited by Marc Nantel, Proc. of SPIE Vol. 9665, 96651C - @ 2007 SPIE, OSA, IEEE, ICO doi: $10.1117 / 12.2207536$ 
Brief descriptions of the main courses are given below.

Table 1. Curriculum of the Biophotonics Master studies at University of Latvia

\begin{tabular}{|l|l|c|c|c|}
\hline No. & \multicolumn{1}{|c|}{ Subject } & Semester & Credits & Part \\
\hline 1. & Modern Physics - 1 & 1 & 5 & $\mathrm{~A}$ \\
\hline 2. & Selected Chapters of Basic Physics & 1 & 4 & $\mathrm{~B}$ \\
\hline 3. & English Terminology of Biomedical Optics & 1 & 3 & $\mathrm{~B}$ \\
\hline 4. & Physics Laboratories - 1 & 2 & 4 & $\mathrm{~A}$ \\
\hline 5. & Fundamentals of Biomedical Optics -1 & 2 & 4 & $\mathrm{~B}$ \\
\hline 6. & Modern Physics - 2 & 2 & 5 & $\mathrm{~A}$ \\
\hline 7. & Human Anatomy & 2 & 4 & $\mathrm{~B}$ \\
\hline 8. & Physics Laboratories -2 & 2 & 2 & $\mathrm{~A}$ \\
\hline 9. & Lasers and Non-Coherent Light Sources & 3 & 4 & $\mathrm{~B}$ \\
\hline 10. & Fundamentals of Biomedical Optics -2 & 3 & 4 & $\mathrm{~B}$ \\
\hline 11. & Medical Lightguides & 3 & 4 & $\mathrm{~B}$ \\
\hline 12. & Physiology & 3 & 3 & $\mathrm{~B}$ \\
\hline 13. & Laboratory-Clinical Praxis & 4 & 30 & $\mathrm{~A}$ \\
\hline 14. & Master Project & & & \\
\hline
\end{tabular}

Fundamentals of Biomedical Optics ${ }^{1}$ as the largest course $(8$ credits $)$ is divided into two parts. The first part includes Tissue Optics (propagation of optical radiation in tissues, skin optics, blood optics, eye optics and optics of the hard tissues) and Optical Sensing for Diagnostics and Monitoring (photoplethysmography, pulse oximetry, laser-Doppler blood flowmetry, NIR monitoring of cerebral oxygenation, optical sensors of physical and biochemical parameters, spectrometric sensors and fluorosensors). The second part covers laser-tissue interactions and laser treatment (medical lasers, laser safety, laser bio-stimulation, laser photodynamic therapy - PDT, laser applications in cosmetology, surgery, dentistry and other medical specialties).

Anatomy and Physiology courses are addressed mainly to the students with physics and engineering background. Its anatomy part regards the composition of human body, structure of brain, heart, kidneys and other organs, as well as the neural, respiratory, reproductive and other essential living systems. The physiology part includes homeostasis, blood supply, muscle dynamics, cellular structures and physiological functions of the basic human organs.

Lasers and Non-coherent Light Sources is a course explaining basic physical principles of non-coherent and coherent light emission. It regards specific features of various laser types (gas, solid state, semi-conductor, excimer, etc.) and their applications in non-linear optics, spectroscopy, environmental studies and medicine. Non-coherent sources like halogen lamps and discharge tubes are regarded, as well.

Medical Lightguides is a course concerning basics of fiber optics and applications of fiber lightguides in various medical devices - fibroendoscopes, "cold light" and non-shadow illuminators, medical laser delivery systems, phototherapy units, bio-optical sensors, etc.

Acquisition of practical skills is a very important aspect of the teaching/training process. Laboratory-Clinical Praxis is included in the study plan at the $3^{\text {rd }}$ semester. During this praxis students spend certain time (at least 6 full days) in real laboratory or clinical environment dealing independently with some particular problem. If this work is successful, it is usually extended at the Master's project. A further step to increase the role of practical activities is development of the specialized student's laboratory. Student practicals concerning optical properties of tissues (laser light scattering from tissue phantoms with subsequent Monte-Carlo modelling), laser-excited skin fluorescence and non-invasive optical diagnostics (photoplethysmography, pulse oximetry and laser-Doppler blood flowmetry) are to be completed in parallel with lectures on Biomedical Optics.

E-learning is a useful tool for the enrolled Master students as well as for those studying independently (so-called "lifelong learning"). Four specialized Biophotics e-courses in the WebCT environment are offered by University of Latvia both Biomedical Optics courses, Medical Lightguides and the Laser course. The contents of e-courses are permanently updated and supplemented with PPT files that are prepared and presented by students during acquisition of those courses. 
In frame of the Swedish-Baltic VISBY project, a short course for medical laser users "Lasers and Bio-optics in Medicine" in English was created in the PowerPoint file format (see details in Chapter 4). This course is formally recognized by the Medical Laser Centre of Lund University and has been approbated internationally in Latvia, Lithuania and Sweden. It may serve as additional contribution to the life-long learning in Biophotonics.

Existence of the specialized Biophotonics library and the specific student's laboratories at University of Latvia proved to be very useful. It became possible thanks to financial support from the European Commission in frame of the TEMPUS project ${ }^{5}$ incorporating five Baltic universities and two from the EU countries (Linkoping University, Sweden, and King's College London, UK). University of Latvia has been recognized as the regional center of excellence on Biomedical Optics teaching in frame of this project. Fruitful international collaboration has been developed also with other European universities, e. g. Lund University (Sweden), University College London (UK), University of Patras (Greece). EU Leonardo da Vinci project on biomedical physics vocational training (including chapters on tissue optics, clinical applications of lasers and medical lightguides) was completed few years ago in collaboration with our Lithuanian, Polish and German colleagues.

\section{SOME PRACTICAL ASPECTS OF THE BIOPHOTONICS TEACHING}

One of the main practical problems was and still is the lack of suitable textbooks in the profile topics. The field is emerging very dynamically, and regular studies of the periodicals - first of all, the journals "Biophotonics" and "Biomedical Optics" - are always necessary. A lot of proved and established knowledge on the topic is available in the review articles, but only few specialized books can be recommended for students. Our Biomedical Optics library now consists of more than 200 units - books (or copies of their chapters), conference proceedings, specialized CDs, periodicals and copies of selected papers. Several most appropriate books for Biophotonics teaching are cited here ${ }^{6-26}$, and selected chapters of them we find quite suitable for the students as basic literature sources. In parallel, Internet resources in the Biophotonics field are growing rapidly, and part of them also might be used as teaching materials. However, some of the topics are presented there incompletely or even totally wrong, so certain web-pages can be recommended to students only after very careful revision by experts of the field.

Biophotonics as emerging inter-disciplinary subject attracts people with different backgrounds. Entrance criteria for enrollment of Biophotonics Master students are very substantial in this respect. At the first years of this program, we enrolled students with Bachelor level diploma in natural sciences, engineering and/or medicine. Further experience led to some limitations - students with medical background were enrolled only after passing the entrance exam in General Physics. That proved to be necessary due to serious differences in physics knowledge if compared with those with natural science (physics, biology, chemistry, geology) or engineering backgrounds.

Generally, several practical problems in the Biomedical Optics teaching area have been identified:

- substantial differences in student's background knowledge levels, especially on physics; medical graduates sometime have difficulties to follow the lectures on special subjects, even after passing the Basic Physics course at the $1^{\text {st }}$ semester;

- the Curriculum does not cover all main aspects of the area; in particular, Medical Imaging, Photosynthesis, Cell Optics and probably some more subjects ought to be added in future, thus changing the existing balance of subjects;

- the Master's study program is time-consuming (2 years), and many students cannot afford to spend all their time for studies; therefore the mean successful output rate for this sub-program has been only about $50 \%$;

- the research activities on the subject would promote teaching quality and therefore should be developed more actively, by attracting additional research resources (human potential and funding);

- the program offers only academic degree without any professional certificate which sometimes can be of value, e. g. for the young clinicians;

- the social need for this kind of specialists is relatively low, and the program has weak support by the local clinical and medical institutions so far;

- harmonization of European education system (in order to meet the Bologna Declaration goals) create some problems - transfer from 4-year to 3-year physics Bachelor program "compresses" the 2-year Master program since some subjects from the $4^{\text {th }}$ Bachelor year are to be moved to the Master program leaving less space there for the specific Biophotonics courses. 


\section{THE SHORT COURSE "LASERS AND BIO-OPTICS IN MEDICINE"}

To avoid laser accidents in hospitals and clinics, all medical laser users should have basic core knowledge on laser principles, laser-tissue interactions, laser safety matters and related items. Obviously, special certified short course is needed for that, preferably not exceeding 4-8 hours. There is a lack of European standards and internationally recognized course programs of this kind. Therefore a special attempt was taken to work out such course titled "Lasers and Bio-optics in Medicine", targeted to medical professionals with little or no background regarding lasers and their clinical applications. This work was done in collaboration with Lund University Medical Laser Centre in frame of the BalticSwedish VISBY project. The elaborated program (see below) can be presented more or less detailed, as one of three options - extensive 8-hour course with 180 color slides (26 MB), basic 4-hour course with 140 slides (22 MB), or brief 2hour course with 95 slides (15 MB). All materials are in English and are intended for modern presentation technology computer projection, using the MS PowerPoint format files.

\section{The proposed certification program for medical laser users}

1. Introduction

2. Laser principles, designs and parameters.

- $\quad$ How the laser works

- $\quad$ Basic types of lasers and their designs

- $\quad$ Gas discharge lasers

- $\quad$ Solid state lasers

- $\quad$ Diode lasers

- $\quad$ The most important laser parameters

3. Basics of tissue optics

- $\quad$ Light absorption and scattering in tissues

- Wavelength effects, the therapeutic window

- $\quad$ Light penetration in tissues

- $\quad$ Absorbing agents in tissues and blood, their spectra

- $\quad$ Skin optics, response to the UV radiation

- Optical parameters of tissues

4. Laser-tissue interactions.

- $\quad$ Photo-thermal effects; examples

- $\quad$ Photo-mechanical effects; examples

- Photo-chemical effects; examples

5. Medical laser systems

- $\quad$ The medical lasers

- $\quad$ Beam delivery systems

- $\quad$ Auxiliary sub-systems

6. Laser and UV safety regulations

- Harmful effects of laser and UV radiation

- $\quad$ Laser safety classes

- $\quad$ The caution and warning signs

- $\quad$ Protective goggles and shields

7. Clinical aspects of laser applications (invited MD's)

- $\quad$ Lasers in therapy and surgery

- Lasers in dermatology and cosmetology

- $\quad$ Lasers in oncology

8. Laboratory training with lasers and tissue samples or phantoms.

9. Certification test/exam. 


\section{DISCUSSION AND CONCLUSIONS}

The significance of Biophotonics as educational subject undoubtedly is growing, and the experience gained over 12 years in University of Latvia may appear useful for development of new or updating the existing teaching methodologies in other universities and colleges. The above-discussed Curriculum has been quite significantly modified during this period, and further amendments are expected in future. One reason is transfer to the Bologna $3+2$ scheme with subsequent changes in physics Master program at University of Latvia. It is proposed that the developed Biophotonics topics will be further integrated in two courses of the new academic Master program and two courses of the professional Master program, all to be developed over the next couple of years.

As a new initiative, an inter-university Master study module on Medical Physics is being developed under support of European Social Fund. It represents a set of 16 courses selected in accordance with recommendations of international experts for obtaining professional certificate in Medical Physics. 8 courses are prepared by Riga Technical University and 8 courses - by University of Latvia, including three of those related to Biophotonics - "Radiation Physics", "Lasers and Optical Methods in Medicine" and "Medical Imaging". Presumably, the gained experience in Master teaching on Biomedical Optics will be helpful in creation of those courses.

The main conclusions are:

- Biophotonics is a rapidly emerging area, therefore every-year updates of the program content are necessary;

- The students are enthusiastic about their studies, but the lack of textbooks in this field makes studies difficult; considerable self-efforts of the students are requested;

- Specialized Biophotonics library and student's laboratory are essential parts of the study process. Student laboratories are very helpful, but expensive; a professionally agreed inter-university methodology is needed;

- Internet resources may be useful in many cases; however, some of the Biophotonics items are presented there incompletely or even totally wrong; how to get rid of them?

- WebCT has proved to be a useful tool for Biophotonics e-studies;

- Further international collaboration on Biophotonics education at all levels should be strengthened by regular meetings and inter-university exchanges of students and teachers;

- Development of specialized regional or international centers seems to be a future trend of providing Master's education on inter-disciplinary subjects like Biophotonics, and University of Latvia is ambitious to become a Baltic regional center in the field of Biophotonics education in future.

\section{ACKNOWLEDGMENTS}

Preparation of this paper and presentation of the corresponding conference report is supported by the European Social Fund project No. 2006/0250/VPD1/ESF/PIAA/06/APK/3.2.3.2./0079/0007.

\section{REFERENCES}

1. J. Spigulis, "MSc course programme on Biomedical Optics", SPIE Proc. Vol. 3190 (Education and Training in Optics, Delft, NL), 1997, pp. 342-345.

2. J. Spigulis. Master's level education in Biomedical Optics: four-year experience at University of Latvia. - SPIE Proc. Vol. 3831 (Education and Training in Optics and Photonics, Cancun, MX), 1999, p. 189-192.

3. J. Spigulis. Teaching of laser-medical topics: Latvian experience. - SPIE Proc. Vol. 4903 (Laser Florence 2001: A Window on the Laser Medicine World, Florence, IT), 2002, p. 197-201.

4. http://www.lu.lv/eng/general/structure/administrative/international.html

5. Y. Dekhtyar, et al., "Joint Baltic Biomedical Engineering and Physics courses", Med. Biol. Eng, Comput., 37, Suppl. 1, 1999, pp. 144-145.

6. A. J. Welsh, M. van Germet, Optical Thermal Response of Laser-Irradiated Tissue, Plenum Press, NY, 1995.

7. J. D. Regan, J. A. Parrish, The Science of Photomedicine, Plenum Press, NY, 1982.

8. S. L. Jacques, Tissue Optics, SPIE Short Course Notes SC34, Bellingham, 1996.

9. M. H. Niemz, Laser-Tissue Interactions: Fundamentals and Applications, Springer, Berlin, 1996.

10. C. A. Puliafito (ed.), Laser Surgery and Medicine: Principles and Practice, Wiley-Liss, NY, 1996.

11. H. W. Lim, N. A. Soter, Clinical Photomedicine, Marcel Dekker, NY, 1993.

12. L. I. Grossweiner, The Science of Phototherpy, CRC Press, Boca Raton, 1994.

13. A. P. Shepard, P. A. Oberg, Laser Doppler Blood Flowmetry, Kluwer Publ., Boston, 1990.

14. A. Katzir, Lasers and Optical Fibers in Medicine, Academic Press, NY, 1993.

15. J. S. Gravenstein, Gas Monitoring and Pulse Oximetry, Butterworth-Henemann, Boston, 1990. 
16. J. P. Payne and J. W. Severinghaus, Pulse Oximetry, Springer, Berlin, 1986.

17. O. Svelto, Principles of Lasers, Plenum Press, NY, 1998.

18. D. H. Sliney (ed.), Laser Safety, SPIE Vol. MS117, Bellingham, 1995.

19. D. Sliney, Safety with Lasers and Other Optical Sources, Plenum Press, NY, 1982.

20. G. J. Mueller (ed.), Laser-Induced Interstitial Thermotherapy, SPIE Vol. PM25, Bellingham, 1995.

21. C. J. Gomer (ed.), Future Directions and Applications in Photodynamic Therapy, SPIE Vol. IS06, Bellingham, 1990.

22. G. J. Mueller et al. (ed.), Medical Optical Tomography: Functional Imaging and Monitoring, SPIE Vol. IS11, Bellingham, 1993.

23. U. Dugnali et al., Optical Imaging of the Brain Functions and Metabolism, Plenum Press, NY, 1993.

24. Handbook of Optical Biomedical Diagnostics (ed. V. Tuchin), SPIE Press, 2002.

25. V. Tuchin. Tissue Optics. SPIE Press, 2000.

26. Biomedical Photonics Handbook (ed. Tuan Vo-Dinh). CRT Press, 2003. 